\title{
Mapping the Future Market Potential of Timber from Small-Scale Tree Farmers: Perspectives from the Southern Highlands in Tanzania
}

\author{
Anne Arvola ${ }^{1}$ (D) $\cdot$ Arttu Malkamäki ${ }^{2,3} \cdot$ Juho Penttilä $^{1} \cdot$ Anne Toppinen $^{2,3}$
}

Accepted: 9 February 2019 / Published online: 18 February 2019

(c) The Author(s) 2019

\begin{abstract}
In the rapidly growing Tanzanian economy, increasing demand for timber and limited wood supply from industrial plantations and natural forests have opened a new livelihood opportunity for smallholder farmers in the Southern Highlands of Tanzania, which is undergoing a tree-growing boom. In the absence of support services, research and statistics, the magnitude of the phenomena has remained unclear, along with the farmers' capability to meet market demands, access the markets, and negotiate prices. Primary qualitative data were collected to clarify the role of smallholder tree growers in the forest transition process and wood value chain using 60 semi-structured tree farmer interviews in four villages, and through interviews of timber buyers and processors. The findings indicate that the strong market demand has created dual markets, where higher quality industrial plantations mainly supply larger industries, whereas micro and small enterprises source wood from lower quality smallholder plantations. While the markets' quality criteria are expected to tighten, capacity building is needed to improve smallholder wood quality to ensure the long-run tree-growing livelihood and competitiveness of small-scale producers in the markets.
\end{abstract}

Keywords Smallholder · Tree plantation · Forest transition · Livelihood diversification $\cdot$ Farmer organizations $\cdot$ Forestry extension

Electronic supplementary material The online version of this article (https://doi.org/10.1007/s 1184 2-019-09414-8) contains supplementary material, which is available to authorized users.

Anne Arvola

anne.arvola@helsinki.fi

1 Viikki Tropical Resources Institute, University of Helsinki, Latokartanonkaari 7, 00014 Helsinki, Finland

2 Department of Forest Sciences, University of Helsinki, Latokartanonkaari 7, 00014 Helsinki, Finland

3 Helsinki Institute of Sustainability Science, Yliopistonkatu 3, 00014 Helsinki, Finland 


\section{Introduction}

The global deforestation rate has halved since 1990, but continues at an alarming rate of $3.3 \mathrm{M}$ ha per year, which mostly occurs in certain poorer countries within the tropical belt (Keenan et al. 2015). The global area of planted forests has, however, nearly doubled since 1990 , totalling $278 \mathrm{M}$ ha in 2015 , which is $7.0 \%$ of total forest cover (Payn et al. 2015). The statistics of developing countries oftentimes report only government-managed plantations and larger-scale industrial plantations (Carle and Holmgren 2008; Payn et al. 2015). Statistics of small-scale tree-growing activities rarely exist, and thus the present and future contribution of smallholders to wood production is difficult to assess (Mayers et al. 2016). Smallholders are, however, becoming increasingly important producers of timber, pulpwood and environmental services, as demonstrated by recent case studies conducted in, for example India, Nepal, the Philippines, Vietnam and the Solomon Islands (Bertomeu 2006; Dubey 2008; Meyfroidt and Lambin 2008; Regmi and Garforth 2010; Ashraf et al. 2015; Versteeg et al. 2017). Smallholder tree growing as such is not a new phenomenon, but the scale of the activity is becoming much more significant than before.

Eastern Africa has population over 400 million people, which is mainly rural and growing fast, and economic growth depends heavily on agriculture (African Development Bank 2018). Declining natural forest resources and climate change pressures are increasingly drawing the interest in plantation grown wood (Lukumbuzya and Sianga 2017). Land scarcity and social risks associated with large scale plantations and their expansion (Malkamäki et al. 2018) make smallholder tree growing and agroforestry systems an attractive option for future tree growing and for example Uganda and Kenya are strongly promoting private and smallholder plantation establishment in their forest policies.

The species and tree-growing systems vary from agroforestry systems with multipurpose trees, to timber production with exotic species in monospecific stands, and are driven by markets, land use intensification or government programmes (Enters et al. 2004; Mather 2007). Byron's global analysis (2001) identified four critical conditions, which need to be simultaneously met so that farm forestry and smallholder tree growing could succeed at a wider scale. These are secure property rights to land and trees: a viable production technology; capacity for crop protection; and adequate markets. Bebbington (1999) identified similar success factors for successful agricultural peasant households: access to land, labour, 'an ability to gain a niche in higher value product markets', and supportive state policy, but he also highlighted the need for external support and (farmer) organisations' role in opening access to knowledge, credit, technical assistance and new markets.

Only recently has the evidence base around the strongly emerging smallholder tree growing in East Africa been paid more attention (Kakuru et al. 2014; Matthies and Karimov 2014; Meijer et al. 2015), with studies revealing that smallholder farmers recognize the livelihood opportunities and other benefits in tree growing, but access to sufficient land, technologies and knowledge are common 
limiting factors. The most successful smallholder tree-growing schemes have involved producing short-rotation wood for example for pulp and paper industries or other industries where timber quality and large diameters are not crucial (Myers 2000). Availability of technical advisory services and access to technologies has also been important, and is even more important if trees are to be grown for sawmilling or the furniture industry (Vermeulen et al. 2008; Race et al. 2009).

Demand for agricultural and forest products is rapidly growing in Tanzania and despite the annual economic growth of 5-8\% (World Bank 2016a), the majority of people live with less than US\$2/day, and the population has grown at a rate of 2.7-3.15\% per year (Fig. 1). Both agricultural and forestry production rely heavily on smallholder farmers and for example $98 \%$ of the maize is produced by them (IFAD 2010; Minot 2010; World Bank 2016b). Modernization and commercialization strategies for improving agricultural productivity have been unable to meet the $10 \%$ annual growth target set by the government, and this growth has barely met the pace of current population growth (Haug and Hella 2013).

The Global Forest Resources Assessment 2015 (FAO 2015) lists Tanzania as one of the top ten countries experiencing the greatest annual net forest loss in 2010-2015 (Fig. 1). The main drivers of deforestation in the Tanzanian Miombo Woodlands are agricultural expansion, charcoal production and fuelwood, and (illegal) logging of high-value timber (Romano and Reeb 2008; Government of Tanzania 2013; Leblois et al. 2017).

Since the 1980s, the forest area per capita has decreased from 3.0 to 1.1 ha in 2012. The estimated annual allowable cut of $0.95 \mathrm{~m}^{3} /$ year/capita cannot meet the average demand for wood, estimated at $1.39 \mathrm{~m}^{3} / \mathrm{year} /$ capita (MNRT 2015). Evidence from forest resource inventories and national statistics (National Bureau of Statistics 2013; FAO 2015; MNRT 2015) indicate that forest scarcity experienced at the regional and national levels (which has caused construction timber scarcity), and smallholder land use intensification in the Southern Highlands (where farmers diversify their livelihoods against economic shocks) are driving forces for tree growing in Tanzania. A supply shift from wood originating from natural forests to plantation-grown softwoods began in the late 1990s (Wells and Wall 2005), when natural hardwood prices were rising due to diminishing sources. Today, government tree

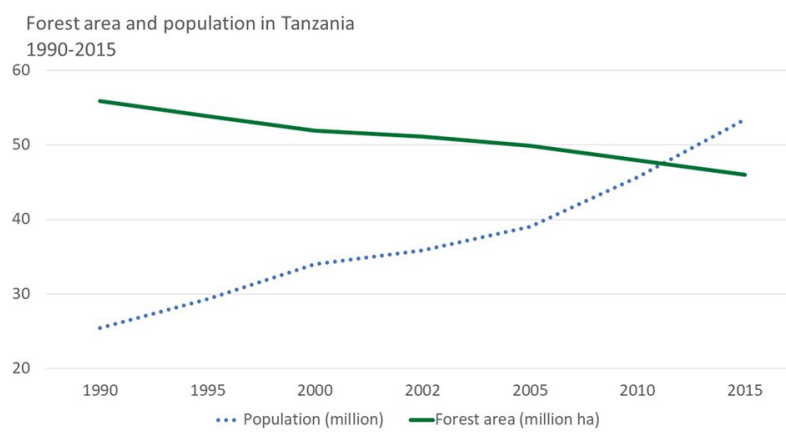

Fig. 1 Forest area and population in Tanzania 1990-2014. (Source: World Bank 2018 and FAO 2015) 
plantations are still the main source for industrial roundwood, but the productivity of Sao Hill, the government's most significant plantation, is declining sharply (Ngaga 2011), and industrial plantations have already been established to some extent to allow wood industries to meet their demands under declining government supply.

The success of the forest policies targeted to support sustainable forest management in natural and planted forests and woodlots depends heavily on both the government's ability to implement forest sector policies and on the success of the agricultural sector in addressing acute development and intensification needs. In Tanzania, the government forest policy (MNRT 1998) and climate change strategies emphasize the role of private sector involvement in forest management and strengthening nation-wide tree-planting programmes (United Republic of Tanzania 2015), but resources to implement these policies and strategies are limited. Only recently have the first donor-supported initiatives to support smallholder tree-growing activities, such as the Private Forestry Programme and the Forestry Development Trust, begun their work in the Southern Highlands. Despite the very limited local-level governmental support, smallholder tree growing has strongly emerged in the Southern Highlands of Tanzania since 2007.

This article examines smallholder tree-growing activities for timber production on village lands. The gap in research and literature on smallholder tree growing in Tanzania and Eastern Africa is vast, and the scattered information available is largely hidden in reports published by projects and institutional financiers. Therefore, the reference base for our study has largely come from research conducted in other countries in the region and from developing countries on other continents.

The purpose of our research is to provide an improved knowledge related to smallholder tree growing, by focusing on pine plantations (Pinus patula) in the Southern Highlands, and on farmers' interaction with and access to timber markets. More specifically, the aims of our research are to increase our understanding of: (1) how farmers integrate tree growing to their livelihood activities; (2) how farmers in the Southern Highlands address and tackle the common problems faced by smallholder tree growers, such as unsecure land tenure; accessing planting materials; poor management skills and market knowledge; and regulation on tree growing and wood sales; (3) how successful smallholder tree growers are in producing high-quality wood, i.e. the share of trees of sufficient quality for sawmilling on smallholder plantations; (4) how they access the markets and what are the prices paid to smallholder tree growers compared to the prices paid for timber from industrial plantations; and (5) what are their future plans for tree growing. Finally, we discuss the likely future research and development needs for smallholder tree growing in the Southern Highlands.

\section{Data and Methods}

\section{Study Area}

The Southern Highlands of Tanzania are experiencing an agricultural and treeplanting boom driven by the country's rapid economic growth. In contrast to other 
regions, Tanzania still has land available for agricultural and forest plantation expansion. A recent study, completed as a continuation of the National Forest Resource Assessment, estimates the Southern Highlands to have 210,000-250,000 ha of tree plantations, 64\% of which are smallholder plantations (Mankinen et al. 2016). Pine, Pinus patula, is the main species planted (67\%), while Eucalyptus spp. and wattle (Acacia mearnsii) plantations cover $33 \%$ of the planted area.

The Njombe region (Fig. 2) is relatively sparsely populated (TNBS 2013), with population growth at $0.8 \%$, which is the lowest rate in the country. Migration from rural to urban areas is visible in the gender ratio, which is only 88 men against 100 women, and household size is lower than the national average. In the two districts the research focused on, Njombe Urban and Njombe Rural, the total population is 216,000 (2012 census) and the districts have 70 and 44 villages respectively.

The combination of fertile soils and climatic conditions make the Southern Highlands and the Njombe region ideal for agricultural production and tree growing. The altitude in the Njombe region varies between 1300 and $2000 \mathrm{~m}$ above sea level, annual rainfall is $1140 \mathrm{~mm}$ and mean annual temperature is $16.4{ }^{\circ} \mathrm{C}$ (Weatherbase 2017).

Maize and beans are the main food crops, and the average area allocated for maize is approximately 0.8 ha per family (Minot 2010). Maize yield is significantly higher than the national average, although still very low compared to the average yield in the developed world or, for example, in Kenya and Zambia (FAOSTAT 2017). The crops are normally continuously cropped until the land fertility and yields decline is severe. Trees (pine) are often planted for the fallow period in the research area (Bisanda et al. 1998; Derksen-Schrock et al. 2011).

\section{Sampling}

Four different villages within the Njombe region (Fig. 2) were selected for our case study to represent variation in access to markets and extension support (Table 1). Road condition is the main factor determining the access to markets from each village. In this study, we determined 'easy market access' to mean less than $2 \mathrm{~h}$ travel time to the main timber yards (Njombe and Makambako).

In each village, 15 households were selected for the tree-growers group and 15 for the non-growers group. Households were identified with the assistance of the village headman, who formulated a list of tree growers and non-growers for sampling and grouped the households as being either wealthy, middle income or poor. The socio-economic ranking was thus subjective, but this way we were also able to reflect the living standards in each village in the ranking. In the tree-growers group, five households were randomly selected from each socio-economic group, but if close kinship was detected between households, we discarded the second selection from the list of interviewees and selected a new interviewee using the same randomized procedure. The village head of Matembwe did not classify any of the tree growers as poor, and thus we sampled ten households identified as average income households. Sampling subjectivity and the reasonably small sample size need to be considered when assessing the reliability of our results and findings: $3.4-9.3 \%$ 


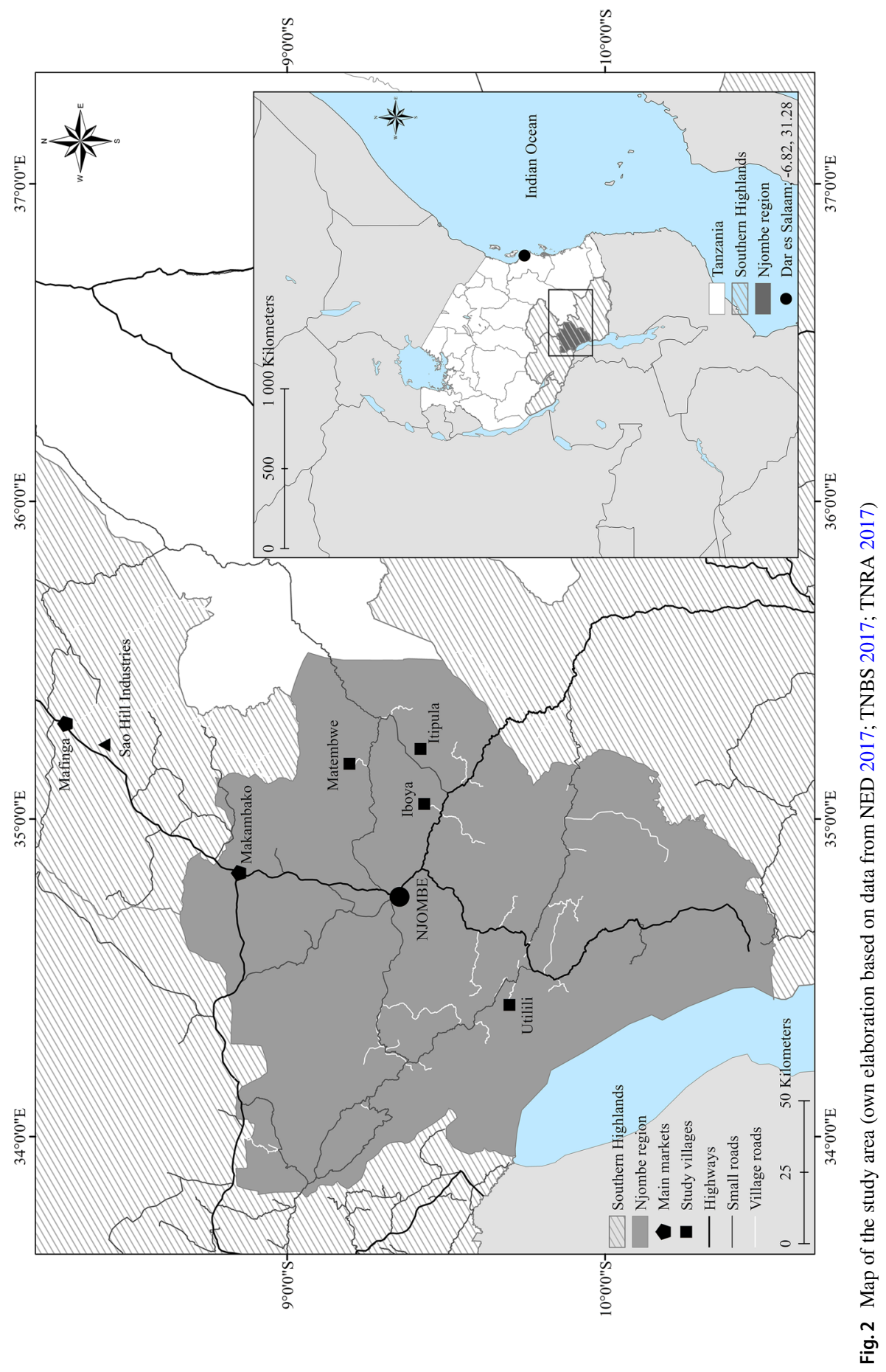


Table 1 Study villages' population statistics and access to markets and extension support

\begin{tabular}{llllllll}
\hline Village & Population & $\begin{array}{l}\text { No. of } \\
\text { house- } \\
\text { holds }\end{array}$ & $\begin{array}{l}\text { Average } \\
\text { HH size }\end{array}$ & $\begin{array}{l}\text { Total vil- } \\
\text { lage area } \\
\text { (ha) }\end{array}$ & $\begin{array}{l}\text { Average area } \\
\text { per HH (ha) }\end{array}$ & Market access & $\begin{array}{l}\text { Receiving } \\
\text { extension }\end{array}$ \\
\hline Iboya & 701 & 215 & 3.3 & 8364 & 39 & Easy & Yes \\
Itipula & 1211 & 295 & 4.1 & 3116 & 11 & Easy & No \\
Matembwe & 3268 & 675 & 4.8 & 18,750 & 28 & Difficult & Yes \\
Utilili & 1475 & 324 & 4.6 & 9873 & 30 & Difficult & No \\
\hline
\end{tabular}

of the households per village were interviewed in our study. Income sub-grouping was only used to diversify the sample of interviewees, not in the data analysis. Key informants (middlemen, wood processors and forest industry representatives) that were interviewed were identified and contacted with the support of the Private Forestry Programme (PFP).

A concrete indication of the scale and significance of tree planting in certain villages was observed during the interviewee selection process. In three villages, the targeted number of 15 non-grower interviewees could not be identified and reached. Tree growing is not quite as common in Utilili, which is furthest from the forest plantation and industries hub located around Mafinga town, and non-growers were identified more easily and they were among the economically active population. In other villages, more than half $(52 \%)$ of non-growers were either young families $(<30$ years) or elderly people $(60+$ years $)$ with very little or no land available.

\section{Data Collection}

The interviews were conducted in May 2015 and they began with a village group meeting where the research team, and the purpose and methods of the research, were introduced to the villagers. The research team explained the confidentiality principles of the research, and the selected households had an opportunity to express their consent to participate in the research and ask questions from the research group. The interviews were carried out individually based on a pretested questionnaire, which included structured and semi-structured questions (see Supplement 1) translated to Kiswahili. The interview took place on the interviewee's woodlot where the inventory data was collected. Experiences from similar studies were reviewed when preparing the questionnaire (Kallio et al. 2011; Gyau et al. 2012; Foundjem-Tita et al. 2013; Meijer et al. 2015). The questions covered basic household information, income sources and their importance, farming activities, detailed information on wood lots and their establishment and management, extension, drivers and challenges of tree growing, and future perspectives. A local extension officer conducted the interviews along with a research team member, and all answers were recorded and translated into English on-site.

One Pinus woodlot of a minimum age of 3 years per each interviewed tree grower was measured to complement the socio-economic interview data (total 60 woodlots, see Supplements 2 and 3). Measurements were made with three circular plots per 
woodlot, taken along a straight line across the woodlot. The woodlot size was measured using GPS tracking and the distances between plots were adjusted according to the woodlot diameter. Different radiuses were used in the circular plots depending on accessibility and tree density. Basic stand measurements were made (see Supplements 2 and 3 for more details) and the amount of undergrowth, signs of soil preparation and slope gradient were recorded for each woodlot. Height was the only variable measured from seedling stands less than two centimetres in diameter.

The stand measurement data were categorized into defect classes to allow analysis, and total biomass volumes per tree were estimated using the equation developed for Pinus patula by Berhe (2009). The calculated volumes do not present commercial volumes, but the share of commercial volume is presumed on average to be a fixed share of the total volume. Seedling stands were excluded from the inventory analysis and uneven aged stands were excluded from the growth analysis.

Market data and price information were additionally collected through the household questionnaire, as well as from interviews with a few timber traders operating in the local and regional markets, and from Tanzania Forest Service (TFS) statistics (Government of Tanzania 2015; Moore et al. 2016). The traders in local and regional markets were interviewed during the visits to timber trade yards as a part of the work carried out in the Private Forestry Programme. Furthermore, we collected additional information on wood markets through key informant interviews with a middleman in Matembwe, tree growers who processed wood themselves (4), local sawmillers association (SAFIA) representatives in Mafinga, a representative of the Tanzania Forest Industries Federation (SHIVIMITA), and in-depth discussions with Private Forestry Programme staff members.

Use of the local forest extensionist as the research assistant had both benefits and disadvantages: local knowledge allowed cross-checking of information in situ and easy formulation of clarifying questions, but it contains a risk that interviewees may not have been willing to share correct information (for example on their income). However, observations during the interview do not support this, and middlemen were, for example, very open in the interviews.

Our study is piloting research with a reasonably small number of interviews and measured plots. Qualitative analysis and descriptive statistics, cross-tabulation, Pearson correlation and Mann-Whitney U test were used to analyse the interviewee material to identify and analyse relationships between socio-economic factors, treegrowing activity, management and market access. Data were triangulated with various sources due to the small sample size per village and data coherence.

\section{Results}

\section{Farmer Profile and the Role of Tree Growing in Their Livelihood Strategies}

Most interviewed households depended on subsistence agriculture based on maize and beans. Out of 60 interviewed tree-grower households, $60 \%$ reported that $90-100 \%$ of the maize grown was for their own consumption only. Non-tree 
Table 2 Significance of different income sources in tree growing households' livelihoods (\% of the total income) in the study villages

\begin{tabular}{|c|c|c|c|c|c|}
\hline & Crops & Animals & Business & Labour & Forestry \\
\hline \multicolumn{6}{|c|}{ Close to markets } \\
\hline Iboya & 76 & 4 & 16 & 0 & 4 \\
\hline Itipula & 40 & 3 & 25 & 7 & 25 \\
\hline \multicolumn{6}{|c|}{ Far from markets } \\
\hline Matembwe & 22 & 12 & 27 & 7 & 32 \\
\hline Utilili & 50 & 44 & 2 & 4 & 0 \\
\hline
\end{tabular}

Table 3 Key characteristics of and differences between planting and non-planting households (conversion rate 1st of May $20151 \mathrm{USD}=1929 \mathrm{TZS}$ )

\begin{tabular}{|c|c|c|c|c|c|c|c|c|}
\hline & \multicolumn{4}{|c|}{ Tree growers (N 60) } & \multicolumn{4}{|c|}{ Non-growers (N 36) } \\
\hline & Min & Mean & $\operatorname{Max}$ & Std.d. & Min & Mean & $\operatorname{Max}$ & Std.d. \\
\hline Age of $\mathrm{HH}$ head & 28 & 46.1 & 78 & 11.84 & 25 & 53.14 & 84 & 16.97 \\
\hline Family size & 1 & 6.28 & 17 & 2.69 & 1 & 4.17 & 10 & 2.47 \\
\hline Income (thousand TZS) & 50 & 1990 & 10,000 & 2152 & 0 & 314 & 1500 & 413 \\
\hline Income/head (thousand TZS) & 10 & 361 & 2250 & 457 & 0 & 78 & 620 & 113 \\
\hline Farm land area (ha) & 0.85 & 7.62 & 43.06 & 6.19 & 0 & 0.79 & 8.09 & 1.61 \\
\hline Area planted with trees (ha) & 0.40 & 5.05 & 13.86 & 3.83 & & & & \\
\hline Share of land planted with trees & 3 & 64.95 & 96 & 21.64 & & & & \\
\hline Share of $\mathrm{HH}$ with sufficient maize & $92 \%$ & & & & $67 \%$ & & & \\
\hline Share of $\mathrm{HH}$ with sufficient beans & $68 \%$ & & & & $44 \%$ & & & \\
\hline Share of HH with external labour & $53 \%$ & & & & $19 \%$ & & & \\
\hline
\end{tabular}

growers reported that on average $74 \%$ of the maize and $61 \%$ of beans was produced for own consumption.

Agriculture was the main cash income source for tree growers in Iboya, Itipula and Utilili (Table 2). During the previous year, forestry was a significant income source in Matembwe and Itipula (8 and 6 respondents), and eight interviewees in Matembwe were also involved in small businesses. Domestic animals were the second most important income source In Utilili (10 interviewees). Fifty-two percent of the tree-grower households also used temporary external labour on their farms (Table 3).

Household income was considerably less in the non-grower group than among the tree growers, they had less land available and they suffered more often from food insufficiency (Table 3). Agriculture was the main income source for nongrowers in Utilili, in all the other villages labour and business were the most important income sources (Table 4). As many non-growers were elderly people or young families, family size was smaller among the non-growers (Table 2). One elderly interviewee in Iboya having no cash income at all, and seven also in Itipula having no cash income. 
Table 4 Significance of different income sources in non-grower households' livelihoods ( $\%$ of the total income) in the study villages
Crops and animals

Labour and business

Close to markets

\begin{tabular}{lrr} 
Iboya & 3 & 97 \\
Itipula & 25 & 75 \\
Far from market & & \\
Matembwe & 38 & 62 \\
Utilili & 95 & 5 \\
\hline
\end{tabular}

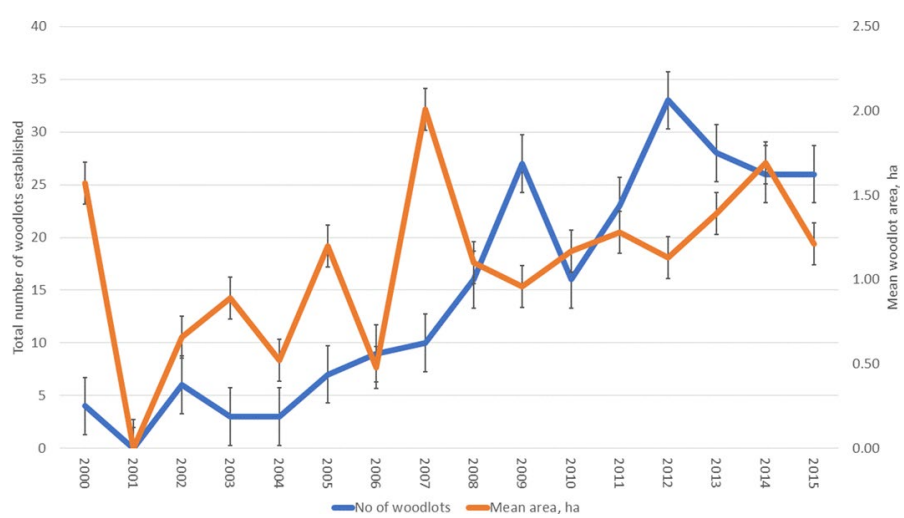

Fig. 3 Number of woodlots established per year and mean area (ha) of established woodlots among the interviewees

On average, tree growers owned four woodlots. Most woodlots (87\%) were pine (Pinus spp.) and $8 \%$ were eucalyptus (Eucalyptus spp.). The majority $(66.7 \%)$ of the woodlots were on former agricultural land, $20.8 \%$ have been established on open land or grassland, $6.3 \%$ on grazing land and $3.1 \%$ were replanted tree plantations.

Tree plantation size has grown over time: prior to year 2000, individual, very small wood lots were established. Since 2007, both the number of plantations established (Fig. 3) and mean plot areas have steadily increased.

\section{Common Challenges in Tree Growing}

\section{Land Tenure and Allocation for Tree Growing}

In Iboya, Itipula and Matembwe, the share of household land allocated for tree growing varied between 18 and $96 \%$ and the mean share between 69 and 77\%. In Utilili, which is further from the markets and where more land is still available, the share varied between 3 and $86 \%$ of the total farm area and the mean share (44\%) was lower compared to the other three villages (Table 5). The association between the area allocated for tree planting and the total land area available was 
Table 5 Land area available (ha) and share of land allocated for tree growing by village

\begin{tabular}{|c|c|c|c|c|}
\hline & \multicolumn{2}{|c|}{ Close to markets } & \multicolumn{2}{|c|}{ Far from markets } \\
\hline & Iboya & Itipula & Matembwe & Utilili \\
\hline Average farm area, tree growers (ha) & 8.7 & 7.2 & 8.8 & 8.8 \\
\hline Average tree growing area (ha) & 7.1 & 5.3 & 5.4 & 2.6 \\
\hline Average farm area, non-tree growers (ha) & 0.3 & 1.5 & 1.4 & 2.7 \\
\hline $\begin{array}{l}\text { Share of land planted for trees, \% (range of } \\
\text { variation in parenthesis) }\end{array}$ & $77(33-86)$ & $69(18-96)$ & $70(48-91)$ & $44(3-86)$ \\
\hline
\end{tabular}

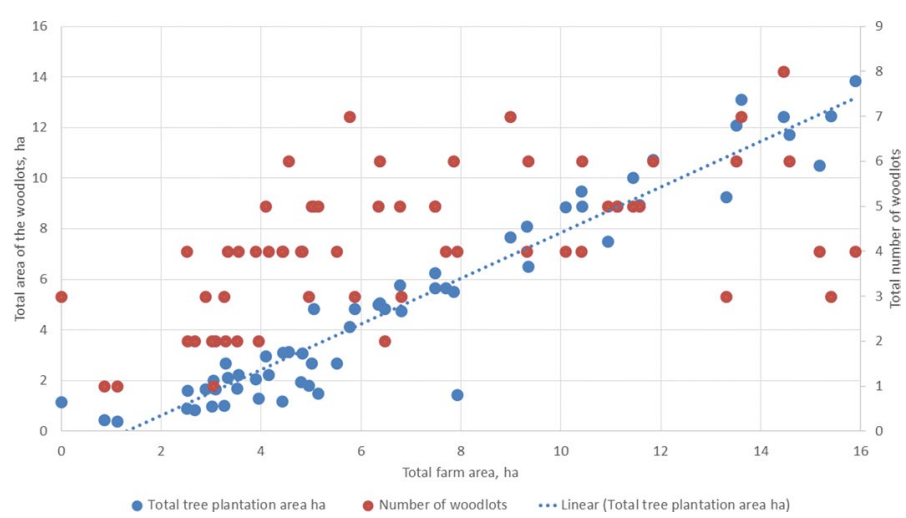

Fig. 4 Share of land allocated for tree growing and number of woodlots

clear ( $p=0.000$, Fig. 4), while household income had no significant correlation with plantation area. The number of woodlots did not increase in a similar pattern and the maximum number of woodlots owned by the interviewees was eight. None of the interviewees had a formal land title for their woodlots, yet only a few mentioned any problems or conflicts in land ownership. The village headman in Iboya mentioned that their village had sold some village lands to an external investor for tree growing, a decision they regret now since they are running out of suitable lands for tree growing.

The primary motivation for planting trees was to produce timber for selling. Timber production was the only motivator for $43.3 \%$ of respondents, while $56.7 \%$ stated that as a secondary product, in addition to timber, they get firewood and/or timber for household use from the plantations.

\section{Access to Planting Materials, Tree Growing Knowledge and Extension Services}

The seeds and seedlings used by tree growers were mainly sourced locally. Collecting seeds from the woodlots in the village (47\%) and growing the seedlings at home or buying the seedlings from the village $(28 \%)$ were the two most common methods for obtaining seedlings. Some farmers had bought seeds from outside the village $(30 \%)$, for example from a company planting trees in the region. In Iboya and 
Matembwe, farmers had received improved seedlings from the Private Forestry Programme for the planting season 2014 and 2015, but these woodlots were not measured in our study. Until recently, farmers have not had access to high-quality seedlings, and the available species and locally produced seedlings have been limited to exotic species such as Pinus patula, certain Eucalyptus sp., Cupressus lusitanica and Acacia species introduced in the region during the last decades. Poor availability of high-quality seeds and seedlings was listed among the major problems in tree growing. Intercropping for the first 1-3 years of tree plantation was applied by $24 \%$ of interviewees, especially when trees are planted on agricultural land (taungya system), but permanent agroforestry systems were not used in the study villages.

Farmers have obtained knowledge on tree growing and plantation management from their families or other villagers, and very few (6) had received any extension or technical advice before the extension projects began in 2010 in Matembwe, and in 2014 in Iboya and Itipula. Less than half $(45 \%)$ of the tree growers reported having received extension support in varying topics, but mainly through the recent extension programmes. District forest office (government) advice has been available for eight farmers, and a few interviewees mentioned missionaries, schools or previous tree-planting and -growing programmes as the source of tree-growing knowledge. Most of the extension received focused on plantation establishment, and early management and pruning were also addressed to some extent (10-12\%). Very few (8\%) said they had received advice on assessing timber value or on marketing or sales.

\section{Quality of Smallholder Produced Wood: Farmers' Investment in Forest Management}

Tree growers were generally willing to invest their time and money in plantation management, and the few exceptions were mainly elderly farmers who could no longer work. Pruning was the most common activity, practiced by three out of four tree growers. However, the work quality was mostly poor, with either long sticks left on the stems or damage caused to the trunks.

The lack of advice and proper tools for plantation management were clearly visible: there were a large number of stem defects caused by poor pruning tools and techniques observed on the recently pruned woodlots that we visited and measured (Fig. 5): in Matembwe all measured woodlots had visible damages caused by pruning, in Utilili 10 and Itipula 3 but Iboya none. However, the low incidence of observed damage in Iboya and Itipula does not mean they would not exist; most of the woodlots measured were more than 6 years old (8 and 11) and pruning damage from earlier years may not be visible anymore. The large number of curved stem bases in the data (14\% of all trees measured) is likely caused by poor planting techniques. Slightly more than half of all trees had no (47\%) or only mild defects (11\%), and they have the potential to produce high-quality wood for timber, while the rest will only be suitable for pulp- or firewood.

No statistically significant association could be found between socio-economic factors and investment in management activities. On the other hand, the better the perceived quality of the plantation, the less forest management activities were performed, as farmers were satisfied with the current condition of their plantations. Most interviewed tree growers allocated less than 10 days per hectare in all 

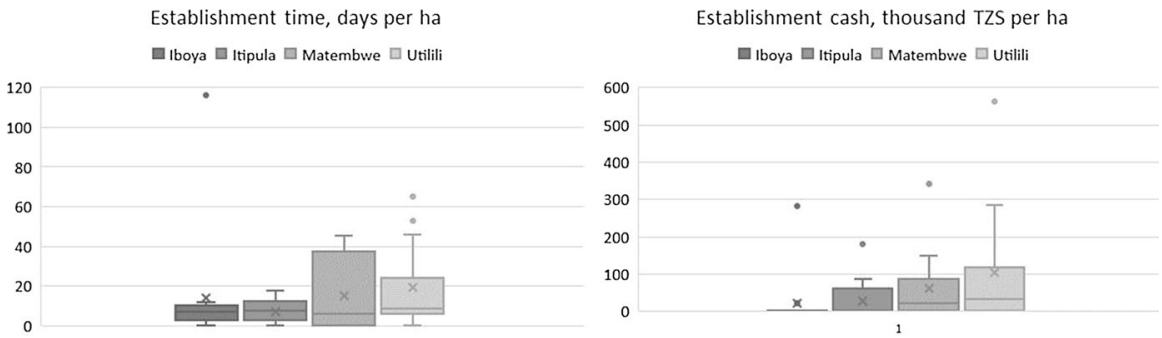

Early management, days per ha

$\square$ Iboya $\square$ Itipula $\square$ Matembwe $\square$ Utilili

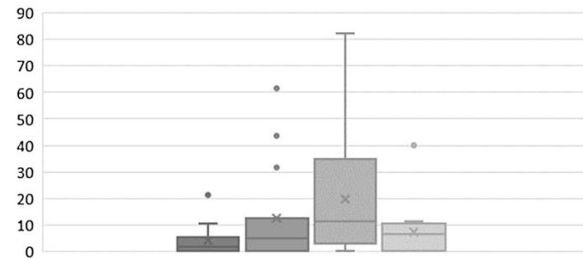

Early management cash, thousand TZS per ha

$\square$ Iboya $\square$ Itipula $\square$ Matembwe $\square$ Utilili

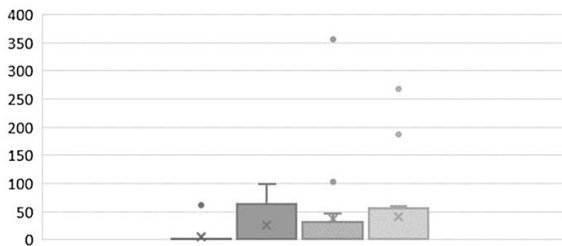

Fig. 5 Damage caused by poor pruning techniques

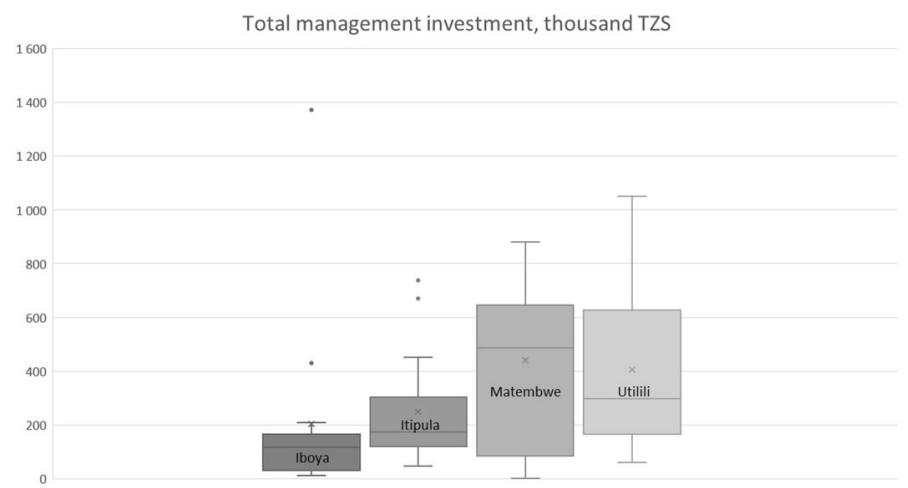

Fig. 6 Comparison of investments made by village during plantation establishment and early management (conversion rate 1st of May $20151 \mathrm{USD}=1929 \mathrm{TZS}$ )

three management phases: establishment, early management (until the time when the first thinning should take place) and late management (time when thinnings should take place) (Fig. 6). A zero-investment made during plantation establishment is explained with intercropping: when trees are planted together with agricultural crops, farmers consider no time to have been spent during the establishment phase.

On average, Matembwe farmers invested the most time in tree plantation establishment and the management of young stands, and their total investment in young stand management was larger compared to other villages (Figs. 6 and 7). To estimate the opportunity cost for the use of labour, the time (days) allocated for plantation 


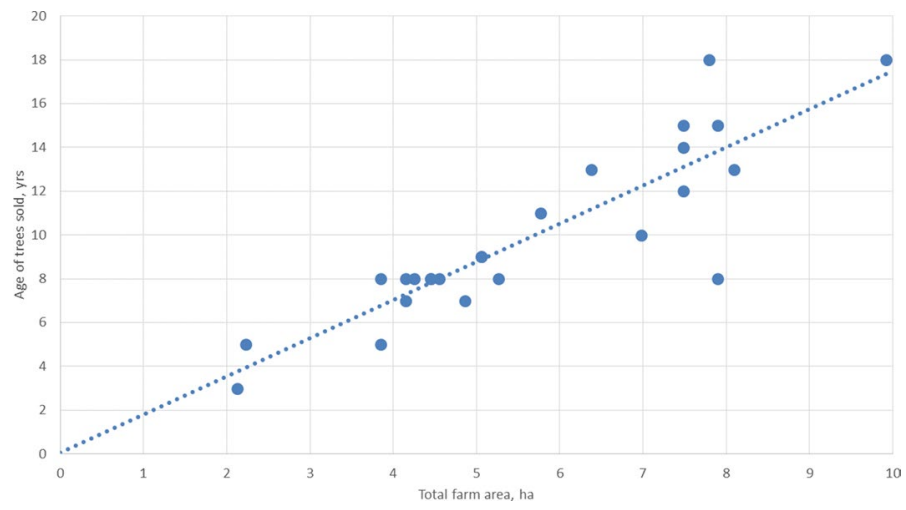

Fig. 7 Comparison of the total plantation investment in the study villages

establishment and management was converted into monetary terms using the local minimum daily salary rate of 10,000 TZS. Slightly more than half $(52.6 \%)$ of the tree growers invested only their household labour during the plantation establishment phase, while $36.8 \%$ invested both labour and cash and $10 \%$ invested only money. Fifty percent of farmers invested household labour only during early management, while $20 \%$ invested both labour and cash. A few (7\%) invested only cash and $24 \%$ had not conducted any early management activities. Farmers considered planting home-grown tree seedlings on agricultural land with crops ('tauynga') as a zero-cost investment.

As an overall trend, the share of trees without defects decreased when the amount of forest management practices increased. In contrast, while the share of trees with severe defects was largely unaffected by the amount of forest management, the share of moderate and especially mild defects increased as more forest management practices were implemented. A similar phenomenon was also observed in the amount of time invested per farmer in young-stand management. When the number of days used for young-stand management increased, the share of trees in severe defect categories grew as well. While other forest management activities negatively affected tree quality to some level, replanting had a statistically significant positive effect.

\section{Farmers' Knowledge of and Access to Markets}

Two-thirds of respondents stated that they already had an idea of their sales strategy at the time of planting the trees. All tree growers in Matembwe and most in Utilili had identified the sales channel from the beginning, while farmers in Iboya and Itipula had been more uncertain. The most common plan was to sell trees to timber traders living in or visiting the village. Four respondents processed and sold timber themselves. Interviewees did not consider wood sales procedures or market access 


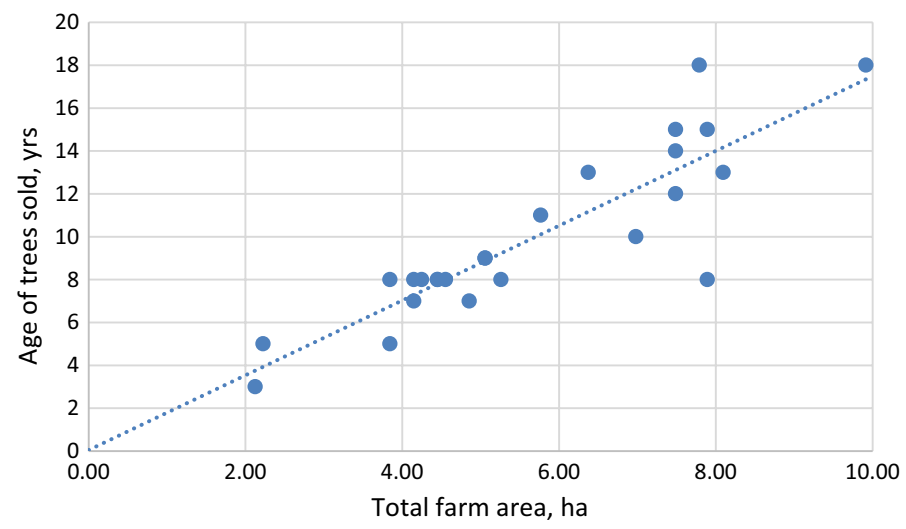

Fig. 8 Correlation between farm total area and age of trees sold

as major obstacles limiting their tree-growing interest and none of the tree growers had paid any fees or licences relates to tree growing or wood sales.

Three out of four respondents had already sold trees or, in three cases, a standing plantation. Utilili differed from the other villages, as only five farmers had sold trees so far. Tree age at the time of sales varied from 3 to 18 years, but only 25 respondents could specify the age of trees sold. Out of these 25 sales, the average tree age at time of cutting was 10.68 years. On smaller farms trees are more likely planted using intercropping, and trees are likely to be sold at a younger age: Fig. 8 illustrates the significance of the area-age dependency $(R=0.88, p<0.001)$, which reflects the pressure to return the land to agricultural use, and the lack of alternative income sources.

Approximately half (47\%) of the interviewed farmers said they had some information concerning market prices at the time of sales. Farmers in Itipula and Matembwe had the best knowledge of market prices, as Itipula is close to the main road and Matembwe had an extension project for several years and a rather developed timber business in the village. Selling to a sawmiller was the most common sales channel in Iboya and Itipula, while it was more common in Matembwe to sell to a middleman living in the village. A few respondents worked in sawmilling.

Based on the interviews with wood traders, two parallel value chains for pinesawn wood actually exist in the Southern Highlands. In the first one, the larger sawmilling industries source timber from mature industrial plantations (especially from the Sao Hill government plantation) and produce higher quality sawn wood. The second value chain is based on smallholder-produced timber, which is processed onsite with transferrable machinery and produces lower quality sawn wood. At the time of the field research, high timber demand, wood scarcity and farmers' needs for cash had led to a situation where wood from smallholder farms is harvested before maturing, which further increases the quality differences between the two value chains.

The pricing of trees sold from smallholder plantations is based on visual assessment only. Based on the growth data of the measured stands, we can estimate that most stands sold fall in the $11-20-\mathrm{cm}$ category and only few in the $21-25$-cm category. 
Table 6 Pricing of pinewood in Sao Hill plantations and prices paid for smallholder-grown wood in the study villages (conversion rate 1st of May 20151 USD=1929 TZS)

\begin{tabular}{lclll}
\hline $\begin{array}{l}\text { The stumpage price in Sao } \\
\text { Hill during the 2015/16 } \\
\text { season }\end{array}$ & & $\begin{array}{l}\text { Prices paid to smallholder growers } \\
\text { 2008-2015 }\end{array}$ \\
$\begin{array}{lllll}\text { Diameter } \\
\text { class }(\mathrm{cm})\end{array}$ & $\begin{array}{l}\text { Total price per } \\
\text { tree TZS }\end{array}$ & $\begin{array}{l}\text { Age of trees at } \\
\text { time of sales }\end{array}$ & Price per tree TZS \\
\hline $11-20$ & 5700 & $7-10$ & $1250-11,330$ \\
$21-25$ & 11,300 & $11-15$ & $2000-10,000$ \\
$26-30$ & 28,300 & $16+$ & $57,143-115,700$
\end{tabular}

The price paid for the two 18-year-old stands gives an indication that their diameter has been in the 26-30-cm category or higher. The price paid per tree on these mature stands is considerably higher than the government stumpage price per tree in the same diameter category (Table 6). The very limited data do not allow drawing wider conclusions on the prices paid, and more studies are clearly needed concerning stand value growth, price formation and payment capacity in the pine value chain.

\section{Future Investments}

Nearly all (93.3\%) of the interviewed tree growers stated that they intend to plant more trees in the upcoming 5 years, and $47.1 \%$ had no preconditions for tree planting. Nearly as many (39.2\%) of the future growers will plant if they have available land, and 5.9\% mentioned that they will increase their plantations if they are able to purchase more land. Pine was clearly the preferred species, firstly due to the ready markets and its marketability (79.5\% of respondents) and secondly due to its rapid growth and quick returns $(31.7 \%)$. The major potential problem respondents perceived in growing trees is the high fire risk, which was mentioned by $70 \%$ of the tree growers and all nongrowers planning to plant trees. Approximately half (53\%) of the non-growers stated that they will, or most likely will, plant trees in the upcoming 5 years, while six nongrowers stated they will with the precondition that they have access to additional land.

The interviewees have increased tree planting every year since 2010, but planting levels dropped in 2015. The decrease in tree planting may indicate that land availability is becoming a limiting factor, but furthermore, the recently introduced extension programme may have had an impact, as farmers are expecting to receive support from the programme in upcoming years and are therefore not investing their own money and resources into tree growing.

\section{Discussion}

\section{Tree Growing in Smallholder Livelihood Strategies: Challenges Encountered}

Farmers rarely have a formal land title, but they clearly consider land ownership in the village land system sufficiently secure for longer-term investments and have great 
interest in tree growing. At regional level land is presently still available for tree growing, although there are differences between villages and accessing more land is the main condition farmers express for expanding their tree growing area. National legislation and regulation does not limit smallholder tree growing on village lands, and lack of bureaucracy has allowed smallholders to respond to increasing wood demand. Despite the fire risk, which $70 \%$ of tree growers and all non-growers considered significant, smallholders consider the tree growing as an attractive business.

At the early stages of the tree growing boom farmers have relied almost completely on locally produced seedlings and only recently the support programmes for smallholder tree growing have introduced improved seedling materials and made them available for selected districts and villages in the Southern Highlands. The same applies to technical knowledge on tree growing: practices have been simply copied from neighbours or relatives. Matembwe had the longest history of extension services (since 2010) and tree growers invested there the most in tree plantation establishment, but this was not visible in the quality of the measured woodlots compared to other villages. Extension support was highly valued in the villages where Private Forestry Programme was working but in 2 years interviewees' attitudes and management practices had not yet changed much. As an example, the improved seedlings the programme had distributed were highly valued, but tree growers had not realized that the benefits the improved seedlings only materialize with improved management practices. Attitudes change slowly, and the change depends on available extension, household social capital and assets. The on-going challenge is for programmes to continue extension activities for long enough to ensure the demonstration effect is created (Kassie et al. 2013).

\section{Quality of the Produced Wood}

The large share of damaged trees and plantations with visible pruning damage is a consequence of farmers' poor forest management skills, and the quality of wood produced is low. Rotation periods are too short from the wood quality viewpoint and farmers consider pine as a fast-growing species with quick returns and the overheated market has supported this (mis)conception. As in many other emerging smallholder tree growing systems, with their limited labour and financial resources farmers prioritize agricultural activities for food security over plantation management and they have no access to additional financing to invest more in tree growing and to prolong rotations (Kallio et al. 2012; Kallio and Kanninen 2013; Nigussie et al. 2017).

The timing and quality of tree plantation management activities play a major role in stand growth and quality, but an indication of willingness to perform plantation management does not necessarily lead to timely and competent implementation of management activities. This results from inadequate technical knowledge among farmers and hired labour, and from the prioritization of agricultural production over tree plantation management. Intercropping is often reported to negatively affect tree stand growth and quality, but Muchiri et al. (2002) observed no such effect in measured woodlots, similarly to our findings. Furthermore, benefits of smallholder 
intercropping systems for the first years of a tree plantation overcome the disadvantages as farmers receive annual income from crops and they do not need to allocate time separately for agricultural and tree growing activities thus weeding and early pruning are carried out properly and on time (Imo 2009).

This study only applied visual assessment for growing tree quality and technical wood properties were not measured. However, the interviewed wood traders mentioned that smallholder timber quality problems are well known: the wood is juvenile and particularly knots, both dead and alive, caused by poor pruning practices or neglected pruning undermine technical qualities of wood.

\section{Farmers' Access to Markets and Market Mechanisms}

Contrary to many other developing economies (Enters et al. 2006; Snelder and Lasco 2008), there is no red tape for a smallholder tree grower as the licensed processors and wood traders carry the administrative burden after the wood sales. Tree growers do not consider access to markets as a constraint, a finding that is contrary to the findings of Kulindwa's recent study (2016) and they are able to get their wood on the market, at least when the market is high. The final trigger for smallholder tree-growing expansion appears to be the regulation issued in 2007, which raised the selling prices of government plantation timber. However, the market mechanism is not well developed, and smallholders rely on local, incidental market contacts. Market information does not reach tree growers very well which leaves them in a weak bargaining position. However, prices paid for smallholders were seen acceptable and in line with the governmental plantation wood prices. The challenge for extension programmes is that an incentive to improve plantation management practices and wood quality is undermined by the over-demand in the wood market, leading to a situation with no major price-quality differences in the market, as only size (diameter), not the quality determines the price paid. The evidence is thin as the number of identified cases is small, but the price paid for mature smallholder grown timber was higher than for governmental plantation wood of similar age, which indicates that smallholders are losing a significant value growth by selling young stands.

So far, distance to markets seemed to have a significant negative effect for tree growing only in Utilili, which was furthest from the wood markets and had no extension services available. Matembwe, on the other hand, had become a smallholder tree growing, processing and trading hub, despite its relative remoteness to the main markets. This could be explained with land availability as the village was large and had plenty of land, and the condition of the gravel road connecting Matembwe to the main roads was relatively good, and the road is passable for large trucks. Also, the extension services since 2010 have likely had an impact on the business development, although the plantation management quality had not improved compared to other villages. Our sample is too small to draw major conclusions on prices paid versus the distance to markets, but the interviews with wood processors and traders confirmed that woodlot topography and distance to roads is a major factor in setting the sales price. 


\section{Future of Smallholder Tree Growing in Tanzania}

Lower than average population (National Bureau of Statistics 2013), land availability and favourable climatic conditions make tree growing possible and feasible in the Southern Highlands. The tree growing area is likely to expand as both the present tree growers and non-growers express a high interest to establish new tree plantations. Land availability, low income and lack of labour, which was in many cases linked to health problems and/or old age, were limiting factors for tree planting among the non-growers. Access to land, not the cash income, defines households' interest to plant trees, which is in line with the findings of Kulindwa (2016). Land use pressure induced by population growth and escalated by the likely impacts of climate change (United Republic of Tanzania 2015) will remain high in Tanzania for years to come and increasing pressure for more agricultural land is likely to push tree growing into more remote areas and poorer sites, where expected returns on tree growing are smaller due to longer rotation ages and/or lower stocking rates that may need to be applied (Capitani et al. 2016; Call et al. 2017). Land holdings will fragment and shrink further due to the subdivision of land for descendants, leading to shortening rotations, especially on plantations established on agricultural land. One development option could be allocation of degraded government forestlands and grasslands for smallholder tree growing, but mechanisms allowing smallholders (not only large investors) access to these lands are missing.

Similarly to many other developing countries (Putzel et al. 2012; Frey et al. 2018), harvesting before the optimal rotation age (that would maximise yield and potential returns) is achieved is common among smallholders in Tanzania. This leads to quality problems which may hamper smallholders access to markets in the future when the market is likely to become more selective and substitutes may replace (poor quality) timber for example as construction material (Indufor 2011). Even though unmeasured variables may dominate the observed tree quality in this study the defects and poor timber undermine smallholders tree growing business and more research is required to establish what is causing the observed defects.

Tree growing in our study villages and in the Southern Highlands is practiced on former agricultural lands, and grass- and shrublands, and thus it is not increasing natural forest loss. However, the impact of tree growing on high-biodiversity grasslands and meadows is highly uncertain (Itambu 2016). Smallholder tree growing is clearly a response to market demand, and it can reduce the pressure on natural forests caused by the increasing demand for timber and wood products.

\section{Conclusion and Future Research Needs}

Farmers are presently using tree growing as an efficient means of livelihood diversification, but the boom may not be sustained and benefits achievable and more widely spread if the productivity of the business and wood quality are not addressed, in conjunction with agriculture (Sikor 2001; Ewers 2006; Mather 2007; Liu et al. 2017). Findings of our study indicate that tree growing in the Southern Highlands is strongly driven by market forces but without addressing the other critical success 
factors, namely viable production technology for quality, supportive state policy and organisational support to facilitate access to knowledge, credit, technical assistance and higher value markets, tree growing may become one more failed cash crop for smallholders. Once wood quality aspects become internalized in the pricing, farmers' inadequate technical skills in forest management will have a negative effect on their access to markets and on the yield of their plantations.

The on-going smallholder tree growing support programmes have highly relevant, but broad and ambitious objectives to improve the support mechanisms for tree growing. Among many other things, Tree Growers' Associations (TGAs) are being established and supported to improve the negotiation power of and services for tree growers, and a Wood Market Information System has recently been launched. The system has the potential to allow full integration of smallholders to the wood markets. Hopefully the donors will keep their preliminary promises of long term commitment and the programmes have enough time to establish solid systems which will be viable after the programmes' closure.

The present legal and institutional framework does not prevent but neither supports smallholder tree growing. Governmental support should be strengthened to out-grow from the present reliance on donor supported programmes. So-called out-grower arrangements, i.e. tree-growing contracts between smallholders and industries, appear a promising method for solving smallholder cash-flow problems leading to non-optimal rotations and for securing technical advice. Out-grower schemes are already being implemented and developed by forest industry companies in the region, with support from the Ministry for Foreign Affairs of Finland, but the scale of the out-grower schemes and technical support services provided is not large enough to cover all tree growers. Thus, success in establishing competent tree grower organizations is a key factor for the long-term sustainability of smallholder tree growing in the Southern Highlands (Bienabe et al. 2004).

Although wood production is the clear priority for establishing plantations in the research area, most farmers also recognized the environmental services that plantations produce. Despite exotic species grown on small woodlots not having the same environmental value as natural forests or native species plantations (Bauhus et al. 2010; Pirard et al. 2016), their impacts on environmental services at local and regional levels, and particularly on national-level deforestation, should be further studied. The foreseen increasing pressures on land use would also require research of alternative production models, considering the wider landscape-level resource allocation, impacts on grassland biodiversity and intensification of production systems at the household level with shorter rotation tree species or agroforestry systems (Muchiri et al. 2002).

The impacts of plantations on the local economy, livelihoods and rural development also requires further research (Baral et al. 2016). The majority of tree growers are poor in absolute terms, and thus the poverty reduction potential through tree growing is significant, although out of reach as a livelihood option, for the poorest of the poor.

Acknowledgements Open access funding provided by University of Helsinki including Helsinki University Central Hospital. The data for our paper were collected in close collaboration and support from the 
Private Forestry Programme in Tanzania, financed by the Ministry for Foreign Affairs of Finland and the Ministry of Natural Resources and Tourism, and implemented with technical assistance support provided by Indufor.

Open Access This article is distributed under the terms of the Creative Commons Attribution 4.0 International License (http://creativecommons.org/licenses/by/4.0/), which permits unrestricted use, distribution, and reproduction in any medium, provided you give appropriate credit to the original author(s) and the source, provide a link to the Creative Commons license, and indicate if changes were made.

\section{References}

African Development Bank (2018) East Africa Economic Outlook 2018. African Development Bank, Tunis

Ashraf J, Pandey R, de Jong W, Nagar B (2015) Factors influencing farmers' decisions to plant trees on their farms in Uttar Pradesh, India. Small-scale For 14:301-313

Baral H, Guariguata MR, Keenan RJ (2016) A proposed framework for assessing ecosystem goods and services from planted forests. Ecosyst Serv 22:260-268. https://doi.org/10.1016/j.ecose r.2016.10.002

Bauhus J, Van Der Meer P, Kanninen M (2010) Ecosystem goods and services from planted forests. Earthscan, London

Bebbington A (1999) Capitals and capabilities: a framework for analyzing peasant viability, rural livelihoods and poverty. World Dev 27:2021-2044. https://doi.org/10.1016/S0305-750X(99)00104-7

Berhe L (2009) Volume and implicit taper functions for Cupressus lusitanica and Pinus patula tree Plantations in Ethiopia. Ethiop J Environ Stud Manag. https://doi.org/10.4314/ejesm.v2i1.43498

Bertomeu M (2006) Financial evaluation of smallholder timber-based agroforestry systems in Claveria, Northern Mindanao, the Philippines. Small Scale For 5:57-81. https://doi.org/10.1007/s1184 2-006-0004-6

Bienabe E, Coronel C, Le Coq J-F, Liagre L (2004) Linking small holder farmers to markets: lessons learned from literature review and analytical review of selected projects. World Bank, Washington $\mathrm{DC}$

Bisanda S, Mwangi W, Verkuijl H et al (1998) Adoption of maize production technologies in the Southern highlands of Tanzania. CIMMYT Sustainable Maize and Wheat Systems for the Poor, Mexico

Byron N (2001) Keys to smallholder forestry. For Trees Livelihoods 11:279-294. https://doi. org/10.1080/14728028.2001.9752396

Call M, Mayer T, Sellers S et al (2017) Socio-environmental drivers of forest change in rural Uganda. Land Use Policy 62:49-58. https://doi.org/10.1016/j.landusepol.2016.12.012

Capitani C, Mukama K, Mbilinyi B et al (2016) From local scenarios to national maps: a participatory framework for envisioning the future of Tanzania. Ecol Soc. https://doi.org/10.5751/es-08565 $-210304$

Carle J, Holmgren P (2008) Wood from planted forests: a global outlook 2005-2030. For Prod J 58:6-18

Derksen-Schrock K, Anderson CL, Gugerty MK (2011) Tanzania: agricultural sector overview. Washington DC

Dubey P (2008) Investment in small-scale forestry enterprises: a strategic perspective for India. Smallscale For 7:117-138. https://doi.org/10.1007/s11842-008-9045-3

Enters T, Durst PB, Brown C, et al (2004) What does it take? The role of incentives in forest plantation development in Asia and Pacific. Food and Agriculture Organization of the United Nations (FAO), Bangkok

Enters T, Durst PB, Brown CL (2006) Stimulating forest plantation development through incentives-in search of the elusive blueprint for success. In: Appanah S, Mansur E, Krezdorn R (eds) Strategic and financial mechanisms for sustainable use and conservation of forests: experiences from Latin America and Asia. FAO, Chiang Mai, pp 102-119

Ewers RM (2006) Interaction effects between economic development and forest cover determine deforestation rates. Glob Environ Chang 16:161-169. https://doi.org/10.1016/j.gloenvcha.2005.12.001

FAO (2015) Global forest resources assessment 2015. FAO, Rome 
FAOSTAT (2017) Food and agriculture organization corporate statistical database. Food and Agriculture Organization of the United Nations (FAO), Rome

Foundjem-Tita D, Tchoundjeu Z, Speelman S et al (2013) Policy and legal frameworks governing trees: incentives or disincentives for smallholder tree planting decisions in Cameroon? Small-scale For 12:489-505. https://doi.org/10.1007/s11842-012-9225-z

Frey GE, Cubbage FW, Ha TTT et al (2018) Financial analysis and comparison of smallholder forest and state forest enterprise plantations in Central Vietnam. Int For Rev 20:181-198. https://doi. org/10.1505/146554818823767582

Government of Tanzania (2013) National Strategy for Reduced Emissions from Deforestation and Forest Degradation (REDD+). Government of Tanzania, Dar es Salaam

Government of Tanzania (2015) The forest regulations, 2015. Tanzania

Gyau A, Chiatoh M, Franzel S et al (2012) Determinants of farmers' tree planting behaviour in the North West region of Cameroon: the case of Prunus Africana. Int For Rev 14:265-274. https://doi. org/10.1505/146554812802646620

Haug R, Hella J (2013) The art of balancing food security: securing availability and affordability of food in Tanzania. Food Secur 5:415-426. https://doi.org/10.1007/s12571-013-0266-8

IFAD (2010) Investing in rural people in the United Republic of Tanzania. Rural Poverty in the United Republic of Tanzania. International Fund for Agricultural Development (IFAD), Rome

Imo M (2009) Interactions amongst trees and crops in taungya systems of western Kenya. Agrofor Syst 76:265-273. https://doi.org/10.1007/s10457-008-9164-z

Indufor (2011) Timber market dynamics in Tanzania and in key export markets market study. Private foresty and carbon trading project, Ministry of natural resources and tourism of Tanzania, Dar es Salaam

Itambu MP (2016) Managing the balance: ecological pressures and heritage resources in Rungwe District, Southern Highlands of Tanzania. J Geosci Environ Prot 04:79-90. https://doi.org/10.4236/ gep.2016.43007

Kakuru OV, Doreen M, Wilson M (2014) Adoption of on-farm tree planting in Kibaale District, Western Uganda. J Sustain For 33:87-98. https://doi.org/10.1080/10549811.2013.776965

Kallio MH, Kanninen M (2013) Factors influencing farmers' tree planting and management activity in four case studies in Indonesia. Trop For Rep 45:108

Kallio MH, Krisnawati H, Rohadi D, Kanninen M (2011) Mahogany and Kadam planting farmers in South Kalimantan: the link between silvicultural activity and stand quality. Small-scale For 10:115132. https://doi.org/10.1007/s11842-010-9137-8

Kallio MH, Kanninen M, Krisnawati H (2012) Smallholder teak plantations in two villages in Central Java: silvicultural activity and stand performance. For Trees Livelihoods 21:158-175. https://doi. org/10.1080/14728028.2012.734127

Kassie M, Jaleta M, Shiferaw B et al (2013) Adoption of interrelated sustainable agricultural practices in smallholder systems: evidence from rural Tanzania. Technol Forecast Soc Change 80:525-540. https://doi.org/10.1016/j.techfore.2012.08.007

Keenan RJ, Reams GA, Achard F et al (2015) Forest ecology and management dynamics of global forest area: results from the FAO Global Forest Resources Assessment 2015. For Ecol Manag 352:9-20. https://doi.org/10.1016/j.foreco.2015.06.014

Kulindwa YJ (2016) Key factors that influence households' tree planting behaviour. Nat Resour Forum 40:37-50. https://doi.org/10.1111/1477-8947.12088

Leblois A, Damette O, Wolfersberger J (2017) What has driven deforestation in developing countries since the 2000s? Evidence from new remote-sensing data. World Dev 92:82-102. https://doi. org/10.1016/j.worlddev.2016.11.012

Liu J, Liang M, Li L et al (2017) Comparative study of the forest transition pathways of nine Asia-Pacific countries. For Policy Econ 76:25-34. https://doi.org/10.1016/j.forpol.2016.03.007

Lukumbuzya K, Sianga C (2017) Overview of the timber trade in East and Southern Africa. TRAFFIC, Cambridge, UK

Malkamäki A, D'Amato D, Hogarth NJ et al (2018) A systematic review of the socio-economic impacts of large-scale tree plantations, worldwide. Glob Environ Chang 53:90-103. https://doi. org/10.1016/j.gloenvcha.2018.09.001

Mankinen U, Koskinen J, Käyhkö N, Pekkarinen A (2016) Remote sensing and participatory based forest plantation mapping of the Southern Highlands, Tanzania. Food and agriculture organization of the United Nations, University of Turku, Dar es Salaam. 
Mather AS (2007) Recent Asian forest transitions in relation to forest transition theory. Int For Rev 9:491-502. https://doi.org/10.1505/ifor.9.1.491

Matthies BD, Karimov AA (2014) Financial drivers of land use decisions: the case of smallholder woodlots in Amhara, Ethiopia. Land Use Policy 41:474-483. https://doi.org/10.1016/j.landusepol .2014.06.012

Mayers J, Buckley L, Macqueen D (2016) Small, but many, is big. Challenges in assessing the collective scale of locally controlled forest-linked production and investment. IIED, London

Meijer SS, Catacutan D, Sileshi GW, Nieuwenhuis M (2015) Tree planting by smallholder farmers in Malawi: using the theory of planned behaviour to examine the relationship between attitudes and behaviour. J Environ Psychol 43:1-12. https://doi.org/10.1016/j.jenvp.2015.05.008

Meyfroidt P, Lambin EF (2008) The causes of the reforestation in Vietnam. Land Use Policy 25:182-197. https://doi.org/10.1016/j.landusepol.2007.06.001

Minot N (2010) Staple food prices in Tanzania. In: Variation in staple food prices: causes, consequence, and policy options, Maputo, Mozambique, 25-26 January 2010 under the African Agricultural Marketing Project (AAMP). Maputo

MNRT (1998) National forest policy. Government of Tanzania, Dar es Salaam

MNRT (2015) National forest resources monitoring and assessment of Tanzania Mainland. Ministry of natural resources and tourism, Tanzania Forest Services Agency, Dar es Salaam

Moore N, Leppänen J, Mwanakimbullah R (2016) Value chain analysis of plantation wood from Southern Highlands. Private forestry programme, Ministry of natural resources and tourism, Iringa

Muchiri MN, Pukkala T, Miina J (2002) Optimising the management of maize-Grevillea robusta fields in Kenya. Agrofor Syst 56:13-25. https://doi.org/10.1023/A:1021180609939

Myers J (2000) Company-community forestry partnerships: a growing phenomenon. Unasylva 51:33-41

National Bureau of Statistics (2013) 2012 Population and housing census. Ministry of finance, Tanzania, Dar es Salaam

Natural Earth Data NED (2017) Natural earth data. Milwaukee. Retrieved from http://www.naturalear thdata.com

Ngaga Y (2011) Forest plantations and woodlots in Tanzania. Afr For Forum Work Pap Ser 1:80

Nigussie Z, Tsunekawa A, Haregeweyn N et al (2017) Factors affecting small-scale farmers' land allocation and tree density decisions in an acacia decurrens-based taungya system in Fagita Lekoma District, North-Western Ethiopia. Small-scale For 16:219-233. https://doi.org/10.1007/s1184 2-016-9352-z

Payn T, Carnus JM, Freer-Smith P et al (2015) Changes in planted forests and future global implications. For Ecol Manag 352:57-67. https://doi.org/10.1016/j.foreco.2015.06.021

Pirard R, Dal Secco L, Warman R (2016) Do timber plantations contribute to forest conservation? Environ Sci Policy 57:122-130. https://doi.org/10.1016/j.envsci.2015.12.010

Putzel L, Dermawan A, Moeliono M, Trung LQ (2012) Improving opportunities for smallholder timber planters in Vietnam to benefit from domestic wood processing. Int For Rev 14:227-237. https://doi. org/10.1505/146554812800923435

Race D, Bisjoe A, Hakim R et al (2009) Partnerships for involving small-scale growers in commercial forestry: lessons from Australia and Indonesia. Int For Rev 11:88-97. https://doi.org/10.1505/ ifor. 11.1 .88

Regmi BN, Garforth C (2010) Trees outside forests and rural livelihoods: a study of Chitwan District, Nepal. Agrofor Syst 79:393-407. https://doi.org/10.1007/s10457-010-9292-0

Romano F, Reeb D (2008) Understanding forest tenure in Africa: opportunities and challenges for forest tenure diversification. Food and Agriculture Organization of the United Nations, Forestry Department, Rome

Sikor T (2001) The allocation of forestry land in Vietnam: did it cause the expansion of forests in the northwest? For Policy Econ 2:1-11

Snelder DJ, Lasco RD (2008) Smallholder tree growing for rural development and environmental services. Lessons from Asia. Adv Agrofor 5:493

TNBS (2013) Population and housing census 2012: census general report. Tanzania National Bureau of Statistics, Dar es Salaam

TNBS (2017) Tanzania National Bureau of Statistics. Dar es Salaam. Retrieved from http://www.nbs. go.tzl

TNRA (2017) Tanzania National Road Agency. Dar es Salaam. Retrieved from http://tanroads.go.tz/

United Republic of Tanzania (2015) Intended nationally determined contributions (INDCs). Government of Lao PDR, Dar es Salaam, Tanzania 
Vermeulen S, Nawir AA, Mayers J (2008) Rural poverty reduction through business partnerships? Examples of experience from the forestry sector. Environ Dev Sustain 10:1-18. https://doi.org/10.1007/ s10668-006-9035-6

Versteeg S, Hansen CP, Pouliot M (2017) Factors influencing smallholder commercial tree planting in Isabel Province, the Solomon Islands. Agrofor Syst 91:375-392. https://doi.org/10.1007/s1045 7-016-9940-0

Weatherbase (2017) http://www.weatherbase.com/. Accessed 15 Feb 2018

Wells J, Wall D (2005) Sustainability of sawn timber supply in Tanzania. Int For Rev 7:332-341. https:// doi.org/10.1505/ifor.2005.7.4.332

World Bank (2016a) Tanzania Economic Update. The Road Less Traveled. Unleashing Public Private Partnerships in Tanzania, Washington DC

World Bank (2016) World bank open data. In: World bank open data. https://data.worldbank.org/. Accessed 1 Apr 2017

Publisher's Note Springer Nature remains neutral with regard to jurisdictional claims in published maps and institutional affiliations. 